\title{
IS THERE A NARRATIVE SUBSTRUCTURE UNDERLYING THE BOOK OF ISAIAH?
}

\author{
Robin Routledge
}

\begin{abstract}
Summary
The recent narrative turn has brought new and helpful insights to biblical studies. This article investigates whether it is legitimate and helpful to look for a possible narrative structure underlying the (generally non-narrative) Book of Isaiah. Starting with the structural model based on the work of A. J. Greimas, it concludes that if this narrative model can be applied to the Book of Isaiah it yields some useful outcomes. It points to the structural unity of the book and helps identify the main theme - in terms of the relationship between God, Israel and the nations, and the role of the Servant of the LORD.
\end{abstract}

\section{A Possible Narrative Structure?}

The purpose of this article is to explore the possibility of applying a particular narrative model to the Book of Isaiah. ${ }^{1}$ The idea of looking for a narrative structure that may underlie non-narrative texts is not new. ${ }^{2}$ With the recent rediscovery by psychologists and social scientists, as well as theologians, of the importance of narrative as a means of giving order and meaning to our personal and spiritual lives, ${ }^{3}$

1 This article was prompted by conversations with Dr Rollin Grams who explored the link between Matthew's Gospel and a possible narrative structure of Isaiah in a lecture at the Oxford Centre for Mission Studies (May, 2003). This article focuses on the Book of Isaiah; however it is hoped that it may contribute to Dr Grams' discussion of Matthew's mission theology.

2 E.g. Richard Hays, The Faith of Jesus Christ - An Investigation of the Narrative Substructure of Galatians 3:1-4:11 (SBL Dissertation Series, 56; Chico, California: Scholars, 1983).

3 E.g. George W. Stroup, The Promise of Narrative Theology (London: SCM, 1984); Gabriel Fackre, 'Narrative Theology: an Overview', Interpretation 37 (October, 1983): 340-52. For an idea of the massive amount of literature on the significance of narrative 
and the recognition that narrative was at least as important to communities in the distant past, it seems reasonable to suppose that even in the compilation of non-narrative texts, the final editors were influenced by narrative structures. That is not to say that they were necessarily conscious of using a particular structure; for many good storytellers that is intuitive. Nevertheless, writing takes place within a particular context; if the writer is to convey meaning, ${ }^{4}$ he cannot avoid using the language and structures available to him. ${ }^{5}$ As a result, whether the author or editor was conscious of using them or not, it should be possible to discern certain structures within the final text. The identification of those structures and of the framework around which the text has been built helps us determine and focus on the key issues within the text and to recognize the text's general movement.

In the following discussion of a possible narrative substructure of the Book of Isaiah we will follow the model put forward by A. J. Greimas. ${ }^{6}$ Before proceeding, it is necessary to offer a brief description of this approach.

According to Greimas, the general framework of the narrative is given by a progression of three sequences. In the initial sequence something has gone wrong: the social order has been disrupted or a contract or mandate has not been fulfilled. In the final sequence the social order or mandate of the initial sequence is restored. Because of

for psychology and other related fields, see the website 'Narrative Psychology: Internet and Resource Guide' at http://www.narrativepsych.com.

4 There is considerable debate about where meaning is located in the relationship between author, text and reader; for further discussion see K. J. Vanhoozer, Is There a Meaning in this Text? The Bible, the Reader and the Morality of Literary Knowledge (Leicester: Apollos, 1998). In particular, the author's intention is often ruled out as a basis for determining meaning. Nevertheless, whatever its significance for the interpretation of the text, we assume the author did have a meaning to convey.

5 E.g. D. Patte, What is Structural Exegesis? (Guides to Biblical Scholarship New Testament Series; Philadelphia: Fortress, 1976): 14-17.

6 This is the model adopted by Hays, The Faith of Jesus Christ. See also N. T. Wright, The New Testament and the People of God (Christian Origins and the Question of God, 1; London: SPCK, 1992): 69-80, 221-23, 373-90; D. Patte, The Religious Dimensions of Biblical Texts: Greimas's structural semiotics and biblical exegesis (Society of Biblical Literature Semeia Studies; Atlanta: Scholars, 1990). For a more complete discussion see A. J. Greimas, Structural Semantics - An Attempt at a Method, (Lincoln/London: University of Nebraska, 1983; tr. from French, 1966, by Daniele McDowell, Ronald Schleifer, Alan Velie); 'Narrative Grammar - Units and Levels', MLN 86 (1971): 793-806; Hays, The Faith of Jesus Christ: 92-103; Patte, What is Structural Exegesis?; J. Calloud, Structural Analysis of Narrative, (SBL Semeia Supplements; Philadelphia: Fortress /Missoula: Scholars, 1976; tr. from French, 1974, by D. Patte). 
their close relationship, the initial and final sequences are described as correlated sequences. Between them is the topical sequence - which contains the heart of the story. A 'hero' is charged with the task of delivering to the subject of the initial sequence what is necessary for the failed mandate to be carried out. If one topical sequence is unsuccessful, another may be introduced. ${ }^{7}$

Within this narrative structure, Greimas identifies actants. These are sometimes characters in the narrative, though they may also be abstractions. At the heart of the structure is the actantial model, which sets out the role of the actants within each sequence. This can be represented diagrammatically, as follows:

$\begin{array}{ccccc}\text { Sender } & \rightarrow & \text { Object } & \rightarrow & \text { Receiver } \\ & & \uparrow & & \\ \text { Helper } & \rightarrow & \text { Subject } & \leftarrow & \text { Opponent }\end{array}$

The Sender initiates the action and determines the Object to be communicated to the Receiver. He then gives a mandate to the Subject to (seek and) deliver the Object. ${ }^{8}$ To assist in this task, the Subject is given a Helper, but is hindered by an Opponent. In this model there are three axes. The axis of communication (Sender $\rightarrow$ Object $\rightarrow$ Receiver) sets out what is to be communicated to whom - and so indicates the aim of the sequence. The axis of volition (Subject $\rightarrow$ Object) defines the role of the Subject within the sequence in terms of the Object that he must deliver. The axis of power (Helper $\rightarrow$ Subject $\leftarrow$ Opponent) sets out the conflict that drives the narrative. To succeed, the Subject, empowered by the Helper, must overcome the Opponent; otherwise he will fail. In the initial sequence this failure is assumed.

7 In the Parable of the Good Samaritan the Priest and Levite passing by represent unsuccessful topical sequences; success comes with the appearance of the Samaritan.

8 Greimas describes the Object as both the 'object of communication', which is delivered by the Subject to the Receiver, and the 'object of desire', which is sought by the Subject (Structural Semantics: 205). The 'object of desire' aspect of the relationship between Subject and Object is not developed in the discussion of Greimas' theory - though in certain narratives, which take the form of a 'quest' it may play an important role. Thus, the Holy Grail (Object) is sought by the Hero (Subject) to deliver it to Mankind (Receiver). The Subject is not merely responding to the mandate of the Sender, but is motivated, too, by his own desire. 
An actant is linked with an action (function) to give a narrative statement. Statements are in turn brought together to form syntagms (semantic units). Each sequence is made up of three syntagms. The contract syntagm (CS) defines the relationship of the actants to one another. A mandate is given by the Sender and, if the sequence is to continue, is accepted by the Subject. A Helper is also provided to assist the Subject to carry out the mandate. ${ }^{9}$ In the disjunction/ conjunction syntagm (DS), the Subject moves to perform the task. ${ }^{10}$ Then, in the performance syntagm (PS) the mandate is carried out. ${ }^{11}$

As we have noted, the initial and final sequences are correlated. The final sequence restores the disrupted social order or the unfulfilled contract of the initial sequence. Hence, the axis of communication in each correlated sequence is the same. So, too, is the axis of volition. The axis of power, though, is different. In the initial sequence the Opponent thwarts the Subject. In the final sequence, the Subject has a different Helper and so is enabled to overcome the Opponent and thus fulfil the mandate. In the topical sequence, the Sender (who may or may not be the same as the Sender in the initial sequence) mandates a new Subject to deliver the new Helper to the initial Subject. This is the purpose of the topical sequence (and as such, is the topic of the narrative). This progression may be represented diagrammatically as follows (where the superscripts ' $I$ ', ' $T$ ' and 'F' denote the actants of the initial, topical and final sequences, respectively). ${ }^{12}$

\subsection{Initial Correlated Sequence}

$\begin{array}{ccccc}\text { Sender }^{\mathrm{I}} & \rightarrow & \text { Object }^{\mathrm{I}} & \rightarrow & \text { Receiver }^{\mathrm{I}} \\ & & \uparrow & & \\ \text { Helper }^{\mathrm{I}} & \rightarrow & \text { Subject }^{\mathrm{I}} & \leftarrow & \text { Opponent }^{\mathrm{I}}\end{array}$

\footnotetext{
9 The helper(s) may be explicit, or may be revealed only as the narrative progresses. The provision, though, is presupposed.

10 In the Parable of the Good Samaritan the Priest and Levite refuse to accept the mandate and ignore the injured man. By contrast the Samaritan accepts the mandate (CS); and goes to him in order to perform the task (DS).

11 For further analysis of syntagms and of narrative statements see Calloud, Structural Analysis of Narrative: 11-18; Hays, The Faith of Jesus Christ: 96-99; Platte, What is Structural Exegesis?: 40-51.

12 In his interpretation of the way this structural analysis works, Wright (in my view mistakenly) does not always maintain this relationship between the actants in the three sequences.
} 


\subsection{Topical Sequence}

\begin{tabular}{|c|c|c|c|c|}
\hline Sender $^{\mathrm{T}}$ & $\rightarrow$ & $\begin{array}{l}\text { Object }^{\mathrm{T}}= \\
\text { Helper }^{\mathrm{F}}\end{array}$ & $\rightarrow$ & $\begin{array}{c}\text { Receiver }^{\mathrm{T}}= \\
\text { Subject }^{\mathrm{I}}\end{array}$ \\
\hline & & $\uparrow$ & & \\
\hline Helper $^{\mathrm{T}}$ & $\rightarrow$ & Subject $^{\mathrm{T}}$ & $\leftarrow$ & Opponent $^{\mathrm{T}}$ \\
\hline
\end{tabular}

\subsection{Final Sequence}

$\begin{array}{ccccc}\text { Sender }^{\mathrm{I}} & \rightarrow & \begin{array}{c}\text { Object }^{\mathrm{I}} \\ \text { T }\end{array} & \rightarrow & \text { Receiver }^{\mathrm{I}} \\ \text { Helper }^{\mathrm{F}}= \\ \text { Object }^{\mathrm{T}} & \rightarrow & \text { Subject }^{\mathrm{I}} & \leftarrow & \text { [Opponent }^{\mathrm{I}} \text { ] }\end{array}$

\section{Application to the Book of Isaiah}

Taken as a whole, the Book of Isaiah is a complex text, which, while it contains substantial narrative sections, is not itself narrative. ${ }^{13}$ However, as we have suggested, it is at least possible that the final redactor of the text was (consciously or unconsciously) influenced by narrative structures. ${ }^{14}$ Because of the breadth of the book and of the theological issues it embraces we may not be able to include all the elements of the text within a narrative framework. However, the existence of a narrative substructure would help us identify the main emphases of the text, and point to the way its argument is developed. It might be of value, too, in providing a structural link between the different sections of the book. ${ }^{15}$

13 For a helpful definition of narrative, see D. M. Gunn and D. N. Fewell, Narrative in the Hebrew Bible (Oxford Bible Series; Oxford: OUP, 1993): 1-3.

14 Literary approaches to the Book of Isaiah are adopted by, e.g. John D. W. Watts, Isaiah 1-33 (Word Biblical Commentary, 24; Waco: Word Books, 1985); Isaiah 3466 (Word Biblical Commentary, 25; Waco: Word Books, 1987); Edgar W. Conrad, Reading Isaiah (Overtures to Biblical Theology, 27; Minneapolis: Fortress, 1991).

15 The following discussion adopts a synchronic approach to the text, and does not address issues such as form, date or authorship. It assumes the existence of one or more final redactor (some may prefer to refer to the book's author), who is responsible for the book in its final form and so for its narrative substructure. Another crucial issue in the Book of Isaiah is historicity, especially of events recorded in chapters $1-39$. We will assume the historical background implied by the text - including the deliverance of Jerusalem, usually dated in $701 \mathrm{BC}$. 
To apply Greimas' structural analysis we need to identify the initial, topical and final sequences and build up an actantial model. The initial sequence presupposes the failure of a Subject to carry out a mandate and that gives us a place to begin.

\subsection{Main Narrative Structure: the initial correlated sequence}

\section{a. Israel's Failure}

The Book of Isaiah begins with a catalogue of Israel's sin. ${ }^{16}$ Though reared and brought up by God, his people have turned away from him. A frequent theme here is Israel's rebellion (Isa. 1:2, 5, 20, 23, 28). ${ }^{17}$ For Isaiah this is at the heart of the nation's $\sin .{ }^{18}$ God has called his people for a purpose, but they have rebelled against him and his will for them. The Song of the Vineyard (Isa. 5:1-7) further highlights the nation's failure to be what God intended it to be. Despite the investment in her of time, effort and affection, God's vineyard (Israel) has not produced the good fruit that he had a right to expect. As a result, the nation faces judgment - though in these opening chapters that is balanced with the promise of eventual restoration, indicating that God's purpose in judgment is to purify and refine, rather than to destroy. ${ }^{19}$

An insight into the consequences of Israel's failure is given in the description of Isaiah's call (Isa. 6). In a vision that had a profound impact on the whole of his ministry, the prophet received an overwhelming revelation of the holiness and glory of God. He saw

16 In the Book of Isaiah the title 'Israel' frequently refers, not to the northern kingdom, but to the whole people of God (as they once were and can be again) - and that is how the term is used in this article.

17 A significant term here is ('sin', 'transgression') (e.g. Isa. 1:2, 28; 27:4; $43: 27 ; 46: 8 ; 48: 8 ; 58: 1 ; 59: 12-13 ; 66: 24)$. This may denote a wilful transgression of the law. However, when set against the background of Israel's covenant relationship with God, this is not just a legal offence: it is an act of deliberate disloyalty; a violation of a sacred trust. As such, it is rebellion against God. See further, A. Luc, 'פשע ( New International Dictionary of Old Testament Theology and Exegesis (NIDOTTE), ed. W. A. VanGemeren, 5 vols. (Carlisle: Paternoster, 1996): 3:706; E. Carpenter and

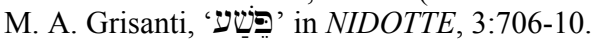

18 See John N. Oswalt, The Book of Isaiah 1-39 (NICOT; Grand Rapids: Eerdmans, 1986): 38-39. Oswalt notes that the book begins and ends with references to rebellion $(1: 2 ; 66: 24)$, suggesting 'a conscious placement on the part of the final editor(s)' ( $p$. $38)$.

19 E.g. Isa. 1:21-26; see J. Bright, Covenant and Promise, (London: SCM, 1977): 105-6. 
God, 'seated on a throne, high and exalted';20 he saw the Seraphim, covering their faces in the presence of God and calling to one another: 'Holy, holy, holy is the LORD God Almighty; the whole earth is full of his glory' (v. 3). Such a revelation of divine holiness and glory caused Isaiah to cry out in despair: 'I am a man of unclean lips' (v. 5) indicating that sin affected his fitness to proclaim God's word. After his confession, the symbolism of the coal touching his lips shows that cleansing from sin also opens the way for his prophetic calling - and we see that in the commission that follows.

As well as acknowledging his own sin, Isaiah is concerned that the people also have 'unclean lips' (Isa. 6:5); implying that they, too, are unfit to proclaim God's word. They, like Isaiah, have a ministry to fulfil, but are prevented from doing so by their sin. It seems probable that the prophet's call has been positioned at this point of the book, rather than at the start, because it points to the possibility of the cleansing and commissioning of the nation as a whole. Israel is called by God but is hindered by $\sin$ (described in Isa. 1-5). Isaiah's experience in chapter 6 opens up the possibility of repentance, cleansing and renewed service. ${ }^{21}$

Whilst implicit in Isaiah 1-39, Israel's call to be God's servant is made explicit in chapters 40-55 (e.g. 41:8-9; 44:1-2; 45:4; 48:20). In most cases this description is intended to encourage Israel that, even in exile, God has not forsaken them and that his purpose for them still stands. In Isaiah 43:10 we are given an insight into what Israel's task includes. Isaiah 43:8-13 is one of several 'trial' speeches, in which God summons the gods of the nations to prove their claim to divinity against his claim to be the only true God. A key element in this is control over historical events - demonstrated in the fulfilment of prophecy (e.g. Isa. 41:23). In Isaiah 43:10 Israel's role is to testify to the faithfulness of God's promises in her history. However the nation has failed. The people are deaf and blind (Isa. 43:8; see also 42:19); they are oblivious to what God has done among them.

This indicates that the Subject in the correlated sequences is Israel. The Sender is God; the Opponent that prevents Israel fulfilling her task

20 Unless otherwise stated, all Bible references are from the New International Version (London: Hodder \& Stoughton, 1979).

21 This argument is put forward by Oswalt. He notes that 'sinful Israel can become servant Israel when the experience of Isaiah becomes the experience of the nation' (Isaiah 1-39: 174). 
includes her rebellion. In order to identify the Object and the Receiver we need to look more closely at Israel's mandate.

\section{b. Israel's Mandate}

We have noted that Israel's task includes testifying to the nations (and their gods) to what God has done in their history. Other passages suggest that as God's servant, Israel is called to display God's glory to the nations (e.g. Isa. 43:7; 49:3).

\section{c. God and the Nations in the Book of Isaiah}

The Old Testament focuses primarily on the relationship between God and Israel. Nevertheless from the beginning we see that God is interested in the non-Israelite nations, and his purpose is to bless them. ${ }^{22}$ Significantly, the nations figure, directly or indirectly, in all the major divine covenants of the Old Testament. The Covenant with Noah includes 'all living creatures of every kind' (Gen. 1:15), and points to God's continuing commitment to his world. In his covenant with Abraham, ${ }^{23}$ God makes promises that relate to the future nation of Israel - but includes, too, a commitment to the nations: 'all peoples on earth will be blessed through you' (Gen. 12:3b). ${ }^{24}$ There is an echo of this, too, in the Davidic Covenant (Ps. 72:17). The Sinaitic Covenant represents a partial fulfilment of the Abrahamic Covenant, and here, again, we see a commitment to the nations. Israel is set apart by God in order to serve him as 'a kingdom of priests' (Exod. 19:6). The priest in Israel was an intermediary. He was consecrated in God's service, with special access to his presence; and there he presented sacrifices and prayers on behalf of the people. He was also a man of the Torah,

22 For a discussion of mission in the OT, see H. H. Rowley, The Missionary Message of the Old Testament (London: Carey, 1955); R. Martin-Achard, A Light to the Nations: a Study of the Old Testament Concept of Israel's Mission to the World (Edinburgh: Oliver and Boyd, 1962); Charles H. H. Scobie, 'Israel and the Nations: An Essay in Biblical Theology', TynBul 43.2 (1992): 283-305.

23 The promises made to Abraham are spread throughout the Genesis narrative. For the purposes of this outline we have avoided the question of whether God made a single covenant with Abraham, or two complementary covenants, and have subsumed all the promises under the general heading 'Abrahamic covenant'.

24 There is some discussion about the precise meaning of the Hebrew expression in this verse. It seems best to take the verb either in a passive (as NIV) or a middle sense ('all peoples ... will find a blessing'). For further discussion see G. J. Wenham, Genesis 1-15 (Word Biblical Commentaries, 1; Milton Keynes: Word, 1991): 277-78. 
bringing God's word to the people. ${ }^{25}$ As a nation of priests, Israel is called to function in a similar way with regard to the nations: bringing God to them and them to God. Israel's acceptance of the mandate is expressed, for example, in Exodus 19:7 - 'The people all responded together, "We will do everything the LORD has said". Despite this enthusiasm, Israel's failure is evident from very early in the nation's history; and it is this failure that underlies the initial sequence in the (proposed) narrative substructure of the Book of Isaiah.

In Isaiah $1-39$, the nations continue to occupy a prominent place. ${ }^{26}$ References to the future blessing of the nations are sometimes linked with allusions to the Exodus. With the installation of the Ark in Jerusalem and the building of the Temple as the place where God had his dwelling and his throne, traditions formerly associated with Sinai were transferred to Jerusalem (Zion); ${ }^{27}$ and in Isaiah 1-39 blessings that had been limited to Israel are widened and made available (implicitly through the ministry of Israel) to the world. Thus, in Isaiah $2: 2-4$, it is the nations who come to Zion to receive God's law (as Israel formerly came to Sinai). In Isaiah 25:6 there is the promise of a 'feast of rich food for all peoples'. It is probable that this follows from Isaiah 24:23, which refers to God reigning on Mount Zion, 'before its elders, gloriously'. The combined reference to elders and to a feast in God's presence recalls Exodus 24:11. The elders of Israel accompanied Moses onto Mount Sinai, where 'they saw God, and they ate and drank'. In the Exodus account, this may refer to a covenant meal, linked with the covenant between God and Israel. In Isaiah 25:6 the meal is shared by all peoples, and emphasises God's desire for a

25 The dual role of Israel's priests is seen in the blessing of Levi in Deut. 33:10. The role of the priest in giving true instruction is emphasised in Mal. 2:4-7.

26 The OT focuses mainly on Israel and Judah, and other nations are often of interest only insofar as they have contact with those kingdoms. The view that this continues in the Book of Isaiah is supported by Friedrich Huber, Jahwe, Juda und die anderen Völker beim Propheten Jesaja (BZAW; Berlin: de Gruyter, 1976). However, see N. K. Gottwald, All the Kingdoms of the Earth (New York: Harper and Row, 1964); W. Eichrodt, Theology of the Old Testament, 2 vols. (London: SCM, 1961, 1967; tr. from German, 1959, 1964), 2:169-73. According to Eichrodt, 'Isaiah had a vision of the divine Providence in its full universality ... it was given to the prophet to perceive ... the far-seeing and constructive plans of God, who willed to lead the nations not into the house of bondage of the Assyrian overseer but into the Father's house of the divine world-ruler' (2:171-72).

27 See J. G. McConville, 'Jerusalem in the Old Testament' in Jerusalem Past and Present in the Purposes of God, ed. P. W. L. Walker (Cambridge: Tyndale House, 1992): 21-51, esp. pp. 25-27. 
relationship with the non-Israelite nations too. This is seen, too, in Isaiah 11:9, a text often related to the coming Messianic kingdom, where the 'holy mountain' appears to be a symbol for the whole world. ${ }^{28}$

Another important passage is the reference to the "community of nations' in Isaiah 19:16-25. The passage begins with a description of God's judgment on Egypt (vv. 16-17) - again using language that recalls the Exodus. ${ }^{29}$ Egypt's fear focuses on Judah (v. 17). As before, God will redeem his people and the Egyptians will be terrified at the display of divine power. The second and third sections of the passage (vv. 18, 19-22) indicate that God's purpose is Egypt's eventual salvation; the coming visitation will cause the Egyptians to turn to God. The next section (v. 23) includes Assyria, too, in the hope of salvation. In the final section the universal scope of divine grace reaches its height, placing Egypt and Assyria alongside Israel as joint heirs of the blessings of God. ${ }^{30}$

An important question raised by these chapters is the relationship between Israel and the nations. At a time of political uncertainty the temptation is to put confidence in what has the appearance of effectiveness and strength - such as the armies of Assyria or the horses and chariots of Egypt. ${ }^{31}$ Isaiah opposes such alliances: spiritually, to trust other nations (and, by implication, their gods) is a denial of true faith in God (e.g. Isa. 7:9; 14:32; 30:15); practically, these alliances cannot deliver the security that the people are looking for. Only God is reliable (as demonstrated by the deliverance of Jerusalem from the

28 See R. E. Clements, Isaiah 1-39 (NCB; London: Marshall, Morgan \& Scott, 1980): 124; J. A. Motyer, The Prophecy of Isaiah (Leicester: IVP, 1993): 125; Watts, Isaiah 1-33: 173. The vision anticipates a universal transformation of creation.

29 In particular, the reference to God's 'uplifted hand' echoes 'the hand stretched out against Egypt' (Exod. 7:5). The drying up of the Nile (Isa. 19:5) may recall the plagues or the miracle at the Red Sea.

30 Egypt and Assyria are significant as Israel's first and most recent oppressors, and probably represent all her political enemies. In the final consummation they will share Israel's relationship with God. Terms previously reserved for Israel are here applied to Egypt and Assyria: 'my people' (e.g. Isa. 10:24; 26:20; 40:1; 43:20); and 'my handiwork' (e.g. Isa. 29:23; 60:21; 64:8). Some distinction may be implied in the description of Israel as God's 'inheritance' (cf. Deut. 32:8-9); the emphasis, though, is on shared blessings.

31 Afraid of the Syro-Ephraimite coalition, Ahaz accepted Assyrian help and became a vassal (Isa. 7:1-17; $2 \mathrm{Kgs} \mathrm{16:7-14).} \mathrm{As} \mathrm{well} \mathrm{as} \mathrm{allying} \mathrm{with} \mathrm{Egypt} \mathrm{(e.g.} \mathrm{Isa.} \mathrm{31:1),}$ Hezekiah was approached by envoys from Philistia (Isa. 14:32), Cush (Isa. 18:1-2) and Babylon (Isa. 39:1-2). 
Assyrians) and God's people are urged to trust him alone. It is ironic that whilst in the coming consummation the nations will recognise their need of Israel's God and turn to him; here, Israel is not trusting God and turning to the nations instead! This reluctance to put her confidence in God alone is another significant factor in Israel's failure to fulfil her mandate.

Although Isaiah 40-55 is mainly concerned with the redemption of Israel, some passages also appear to envisage the future salvation of the nations (e.g. 42:4, 6; 45:22; 49:6; 55:4-5). ${ }^{32}$ A significant factor in the turning of the nations to God is the revelation of his power when he redeems and restores Israel (e.g. Isa. 44:23; 45:14; 52:10). The theme of the nations turning to God begins and ends the final section of the book. Along with the exiles of Israel, God will gather from other nations those who commit themselves to serving him (Isa. 56:3-8). They will be drawn to the divine glory that shines from his renewed and restored people (Isa. 60:1-3). But Israel's role in the winning of the nations is not merely passive, and in the closing verses of the book we see God's people performing the somewhat unfamiliar task of going out to the nations in order to bring them back to worship God in Jerusalem (Isa. 66:18-19). ${ }^{33}$

In the light of the emphasis on the nations in the Book of Isaiah, it is not unreasonable to see them, collectively, as the Receiver of God's Object of communication. The implications of this for our

32 There are also passages that appear to envisage Israel's salvation only against the background of the defeat and subjugation of the nations (e.g. Isa. 45:14; 49:7,23), and this has led some to argue that Deutero-Isaiah was a nationalistic prophet concerned exclusively with Israel; e.g. N. H. Snaith, 'Isaiah 40-66' in Studies in the Second Part of the Book of Isaiah (VTSup, 14; Leiden: Brill, 1967): 135-264; R. N. Whybray, The Second Isaiah (Old Testament Guides; Sheffield: JSOT, 1983): 62-65. However, the universalistic aspect of the message is not readily explained away. The tension between universalism and nationalism may be partly explained by the focus on Israel as God's instrument of revelation to the world; see R. Davidson, 'Universalism in Second Isaiah', SJT 16 (1963): 166-85; H. G. M. Williamson, Variations on a Theme, King Messiah and Servant in the Book of Isaiah (Didsbury Lectures; Carlisle: Paternoster, 1998): 122-28. See also A. Gelston, 'The Missionary Message of Second Isaiah', SJT 18 (1965): 308-18; J. Blenkinsopp, 'Second Isaiah - Prophet of Universalism', JSOT 41 (1988): 83-103; H. Halas, 'The Universalsm of Isaiah', CBQ 12 (1950): 162-70; D. E. Hollenberg, 'Nationalism and the nations in Isaiah XL-LV', VT 19 (1969): 23-36.

33 The 'survivors' are most likely Israelites who have come through God's judgment on the nation; see John N. Oswalt, The Book of Isaiah 40-66 (NICOT; Grand Rapids: Eerdmans, 1997): 688; J. Goldingay, Isaiah (NIBC; Carlisle: Paternoster, 2001): 373; Blenkinsopp, 'Second Isaiah - Prophet of Universalism': 98. 
understanding of the purpose of the book as a whole will be considered below. For the moment, though, we need to the identity of the Object. There are several possibilities, including faith in God, salvation and the blessings of the coming kingdom. All of these are available to the nations. However, what stands out in the Book of Isaiah, as the overarching purpose of God, is the revelation of his holiness and glory.

\section{d. The Glory of God in the Book of Isaiah}

At his call, Isaiah had an overwhelming first-hand experience of the holiness and glory of God. The seraphim hid their faces as they proclaimed the intensity of his holiness, and declared that his glory filled the earth (Isa. 6:3). There is a close relationship between holiness and glory. Holiness may be seen as an inward characteristic; it is an essential divine attribute, intimately related to who God is. ${ }^{34}$ Glory is the outward manifestation of that holiness: the radiant splendour of the presence of God. ${ }^{35}$ So in Isaiah 6:3, the reference to the glory of God filling the earth is not separate from the ascription of glory, but is the corollary of it. The significance of the holiness of God for the Book of Isaiah is also seen in the frequent description of God as the 'Holy One of Israel'. ${ }^{36}$

The Book of Isaiah makes several specific references to the plan or purpose of God. ${ }^{37}$ These passages have different emphases; however the revelation of God's holiness and glory may be discerned as a common thread running through them. God's intention to destroy Assyria (Isa. 14:14-27) because of the nation's pride in overstepping the limits set by God on her action (e.g. Isa. 10:7, 12-14), is part of a 'plan determined for the whole world' (Isa. 14:26), which includes bringing low all those who exalt themselves and so usurp a glory that belongs to God alone (cf. Isa. 42:8). This is seen even more clearly in the reasons given for divine judgment on Tyre: 'The LORD Almighty

\footnotetext{
34 See J. A. Naudé, 'קדש' in NIDOTTE: 3: 877-87.

35 See Eichrodt, Theology of the OT, 1:277-80; O. Kaiser, Isaiah 1-12 (OTL; London, SCM, 1972): 78-79; N. H. Snaith, Distinctive Ideas of the Old Testament (London: Epworth, 1944): 48-50.

36 The expression occurs 30 times in total in the OT, of which 25 are in the book of Isaiah, i.e. $1: 4 ; 5: 19,24 ; 10: 20 ; 12: 6 ; 17: 17 ; 29: 19 ; 30: 11,12,15 ; 31: 1 ; 37: 23$ (=2 Kgs $19: 22) ; 41: 14,16,20 ; 43: 3,14 ; 45: 11 ; 47: 4 ; 48: 17 ; 49: 7 ; 54: 5 ; 55: 5 ; 60: 9,14$. God is also described as 'the Holy One' (40:25), and 'the Holy One of Jacob' (29:23); see also $5: 16 ; 10: 17 ; 43: 15 ; 57: 17$.

37 Isa. 5:19; 14:24, 26-27; 19:12, 17; 22:11; 23:8-9; 25:1; 37:26; 46:10-11. See also, J. Fichtner, 'Jahwes Plan in der Botschaft des Jesajas', ZAW 63 (1951): 16-33.
} 
planned it, to bring low the pride of all glory and to humble all who are renowned on the earth' (Isa. 23:9). This demonstration of God's ultimate authority over the nations may be seen as a further outworking of Isaiah 6:3 - 'the whole earth is full of his glory'.

Alongside God's intention to humble the pride of nations, God also reveals his glory to the world by demonstrating his presence and power in and through his people. On Israel's journey through the desert, the glorious presence of God first encountered on Mount Sinai continued with them (Exod. 40:34-38; Num. 9:15-23). The same divine glory that filled the Tabernacle in the desert filled Solomon's Temple in Jerusalem (1 Kgs 8:10-11); and Isaiah's vision of God's glory, also in the Temple, confirmed the presence of God among his people. And the glory seen at the Exodus, in the cloud that accompanied the people from Sinai, is also linked with God's presence on Mount Zion (Isa. 4:5). God's purpose in revealing his glory to Israel is that they, in turn, make God's glory known to the world (Isa. 43:7; 49:3). A significant aspect of this is the demonstration of divine power on Israel's behalf, bringing deliverance and vindication. This is evident, too, in the events of the Exodus, where God's victory over Pharaoh resulted in him being given glory (Exod. 14:17-18).

Despite God's purpose for them Israel's history testifies to her failure to display God's glory to the world. Indeed, Ezekiel accuses the people of having brought dishonour to God's name (Ezek. 36:20-21). However, though in the initial sequence of the narrative, Israel has not fulfilled her mandate, God's intention has not changed. Just as he brought Israel out of Egypt, so God will deliver his people from exile; he will show his power over Babylon and its gods, and so reveal his glory to a watching world. ${ }^{38}$ The result of God's activity in redeeming and restoring Israel is that they will once again display his glory among the nations (e.g. Isa. 55:5; 60:1-3; 62:2; 66:18-19). There is a close link between what is announced in Isaiah 40, and its fulfilment in Isaiah 65-66;39 and in particular in relation to the revelation of God's glory to the world (Isa. 40:5; cf. 66:18-19).

38 The redemption and vindication of Israel is directly linked with the revelation of God's glory or splendour in Isa. 40:5; 44:23; 46:13. In other passages it results in the recognition by the nations that Israel's God is the one true God (e.g. Isa. 43:9-13; 45:14).

39 B. S. Childs, Isaiah (Old Testament Library; Louisville: Westminster John Knox, 2001): 543, notes significant intertextual parallels between these sections. 


\section{e. Helper and Opponent}

Before setting out the actantial model of the initial sequence, we need to ask what assistance Israel was given in her mission to deliver God's glory to the nations, and to elaborate on what prevented her from fulfilling that mission. To identify the Helper we can go back to Moses and the Exodus and the revelation of God's glory then. The Book of Isaiah alludes to this period directly and indirectly - in God's election of Israel to be his servant (e.g. Isa. 41:8-10; 43:1; 44:1-2) and his activity in the nation's history (e.g. Isa. 43:10; 44:8). Part of the reason for Israel's initial failure is external: the idolatry and pride of the nations. That is something we will return to. The principal difficulty, though, is with Israel herself; and we have already noted her rebellion, and her unwillingness to trust God alone.

\section{f. Actantial Model for the Initial Correlated Sequence}

The foregoing discussion allows us to construct the following actantial model for the initial correlated sequence.

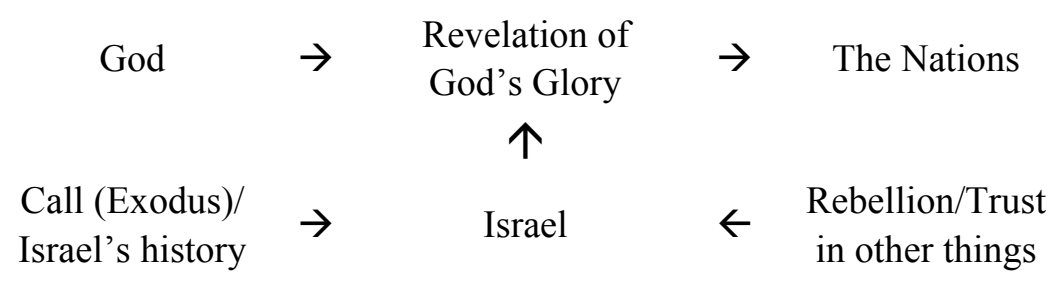

In the contract syntagm, the mandate is given by God and accepted by Israel, principally in the context of the Exodus and the Sinaitic Covenant (e.g. Exod. 19:6-7). Israel's movement to fulfil that mandate (the disjunction syntagm) is seen in her separation from the nations, as a kingdom of priests. The performance syntagm is lacking, since in this sequence the mandate remains unfulfilled. To continue the analysis, we need to look at the provision of a new Helper that will enable Israel to overcome the Opponent and so be successful in the final sequence. This Helper is the Subject of the topical sequence.

\subsection{Main Structure: Topical and Final Sequences}

\section{a. Topical Sequence (1) - Isaiah's Ministry}

Isaiah is called to point out Israel's failure and call the nation to repentance and faith. In this sequence, he is helped by the revelation of the holiness, glory and majesty of God at his call. He is opposed by the 
deafness and blindness of the people to whom he is sent. This gives the following actantial model:

God $\quad \rightarrow \quad$ Repentance/ Faith $\rightarrow \quad$ Israel

$\uparrow$

Revelation of
God at his call $\rightarrow \quad$ Isaiah $\quad \leftarrow \begin{gathered}\text { Israel's deafness } \\ \text { and blindness }\end{gathered}$

Before Isaiah could serve as God's messenger, he first needed to experience God's cleansing and renewing power in his own ministry. The prophet's call in Isaiah 6 may be seen as a sub-theme within the narrative; ${ }^{40}$ here again the narrative structure is evident.

\section{b. Sub-narrative: Isaiah's Call}

Initial Correlated Sequence

$\begin{array}{ccccc}\text { God } & \rightarrow & \text { Repentance/ Faith } & \rightarrow & \text { Israel } \\ & & \uparrow & & \\ {[]} & \rightarrow & \text { Isaiah } & \leftarrow & \text { Unclean lips }\end{array}$

Topical Sequence

God
$\begin{gathered}\text { Cleansing/ } \\ \text { Renewal } \\ \uparrow\end{gathered}$$\quad \rightarrow \quad$ Isaiah

$\underset{\text { Beraphim }}{\text { Burning coal }} \rightarrow$ Confession $\quad \leftarrow \quad$ [ ]

Final Correlated Sequence

God $\quad \rightarrow \quad$ Repentance/ Faith $\rightarrow \quad$ Israel

$$
\uparrow
$$

Cleansing $/$
Renewal $\quad$ Isaiah $\quad \leftarrow \quad$ [Unclean lips]

40 See Patte, What is Structural Exegesis?: 51. 
As we have seen, Isaiah's call is significant for the book as a whole. It reveals the holiness and glory of God, and so sets the direction of the prophet's ministry. It also gives a pattern for what God wants to do in the life of Israel. In this topical sequence Isaiah's ministry, and his ability to bring Israel to a place of true repentance and faith, is thwarted by the spiritual deafness and blindness of the people to whom he is sent (Isa. 6:9-10). Nevertheless, in his message he sets out clear theological guidelines for the way Israel should go in order to fulfil its calling. His call to repentance and faith, though, was ultimately unsuccessful. The Assyrian attack on Jerusalem did bring the nation to its knees, and with nowhere else to go the people turned to God; ${ }^{41}$ however, after the deliverance things went back to the way they had been. ${ }^{42}$ The report of the visit of envoys from Babylon (Isa. 39) demonstrates Hezekiah's pride in his own resources and his willingness to enter into an alliance with Babylon - both of which point to a lack of faith in God alone. This took place before the deliverance of Jerusalem; it is recorded out of chronological sequence probably to indicate that things have not really changed. The change of heart brought about by the Assyrian crisis was only temporary. The nation failed to respond to Isaiah's call to faith. As a result, the Exile became inevitable as a means of bring the people to their senses.

The prophets view the Exile both as God's judgment on sin and as the means by which God would bring about a necessary new beginning for his people. The nation must die before it can be reborn; renewal could come only when all pretensions and false hopes had been swept away. God would use the fire of judgment and exile to refine and purify his people, and so bring them (or a remnant of them) into a new era of salvation. However, historical crises alone cannot bring the spiritual renewal that is needed; so, in Isaiah 56-66, generally thought to be set in Palestine after the return from exile, the same old problems of greed, injustice, and empty worship need to be addressed. The Exile

41 I have argued that there were two elements in the deliverance of Jerusalem from Sennacherib: Assyrian pride and the last minute repentance and prayer of Hezekiah and the people; see R. Routledge, 'The Siege and Deliverance of the City of David in Isaiah 29:1-8', TynBul 43.1 (1992): 181-90.

42 This appears to be the emphasis of Isa. 22:1-14. A likely setting for this is the people's rejoicing after the deliverance of Jerusalem from the Assyrians in $701 \mathrm{BC}$. However, rather than allowing the disaster to drive the people to repentance and renewed trust in God (v. 12), the focus is on the human preparations for the siege (vv. 8b-11), and self-congratulatory celebration (v. 13); see J. Bright, The Kingdom of God (Nashville: Abingdon, 1985): 90-91; Childs, Isaiah: 161. 
plays its part; but the Book of Isaiah as a whole indicates the need for something more. God's provision for Israel's spiritual needs is seen in the ministry of God's Servant.

\section{c. Topical Sequence (2) - God's Servant}

There is considerable debate about the identity of the figure referred to in what have been termed the 'Servant Songs' ${ }^{43}$ Various suggestions have been put forward - including the view that the Servant is Israel herself. ${ }^{44}$ Our approach focuses on the narrative role of the Servant rather than on his identity. However it is unlikely that the Servant in the Servant Songs is Israel. It is true that in Isaiah 49:3 that identification appears to be made: you are my servant, Israel, in whom I will display my splendour. In later verses, though, it is clear that the Servant has a ministry to Israel (Isa. 49:5-6). Part of that ministry is to demonstrate perfect servanthood, and so to be what Israel has so manifestly failed to be - and that is seems to be the significance of Isaiah 49:3. The Servant is Israel in the sense that he embodies all that Israel was created to be. ${ }^{45}$ This includes fulfilling Israel's mandate to reveal God's splendour (Isa. 49:3) and to be a witness to the nations (Isa. 49:6).

In the context of the people's suffering in exile, the Servant's ministry also involves bringing comfort and strength to the bruised and the weary (Isa. 42:3; 49:4; 53:4). Through him, too, God will bring restoration (Isa. 49:5-6), and atonement for $\sin$ (Isa. 53:4-6, 11-12) - so that the Servant not only demonstrates, but also enables Israel to become, what she was created to be. How he will do this is not explicitly stated; though the Servant's obedience to God and his commitment to see his task through (Isa. 42:4; 49:4; 50:5-7) - despite rejection, hostility and (probable) death (e.g. Isa. 50:6; 53:3, 8-9), ${ }^{46}$

43 Isa. 42:1-4 (9); 49:1-6; 50:4-9; 52:13-53:12 are regarded as distinct units, with a distinct emphasis.

44 See S. Mowinckel, He That Cometh (Oxford: Basil Blackwell, 1959): 187-257; C. R. North, The Suffering Servant in Deutero-Isaiah (Oxford: OUP, 1948; H. H. Rowley, The Servant of the Lord and other Essays on the Old Testament (London: Lutterworth, 1952): 1-88. For a more recent summary, see G. P. Hugenberger, 'The Servant of the Lord in the "Servant Songs" of Isaiah' in The Lord's Anointed: Interpretation of Old Testament Messianic Texts, eds P. Satterthwaite, R. Hess (Carlisle: Paternoster/Grand Rapids: Baker, 1995): 105-40.

45 See Childs, Isaiah: 383-85; Goldingay, Isaiah: 281-82; Oswalt, Isaiah 40-66: 291.

46 Isa. 53:7-9 is usually taken to point to the Servant's death. R. N. Whybray, Thanksgiving for a Liberated Prophet: An Interpretation of Isaiah 53 (JSOTSup 4; 
plays an important part. To help him in the performance of his task, God's Servant is endowed with the Spirit (Isa. 42:1) and equipped to hear God and proclaim his word (Isa. 49:2; 50:4-5).

From this we can build up the following actantial diagram.

\section{God}

Spirit/Enabled

to proclaim

God's word
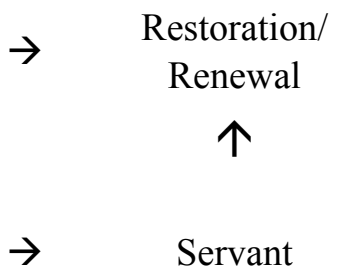

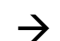

Israel

In the contract syntagm, the Servant receives his mandate from God (e.g. Isa. 42:1; 49:1, 5; 50:4). The acceptance of the call is seen in passages that point to his willingness to persevere in his task, despite difficulty and opposition (e.g. Isa. 42:4; 49:4b, 5b;50:5b-7; 53:7). We see here, too, the provision of the Helper(s) that will enable the Servant to be effective in fulfilling his mandate. In the disjunction/conjunction syntagm the Servant's movement is both negative and positive. He does not draw back or try to hide from suffering (Isa. 50:5-6; 53:7); instead he sets his face like flint in the direction of his mission (Isa. 50:7b). Finally, in the performance syntagm the Servant confronts the need of Israel, who, after initial opposition, recognises the importance of his ministry (Isa. 53:1). The Servant faces and overcomes rejection and hostility and remains true to his calling (Isa. 42:4; 50:7-9); consequently he is successful in bringing the needed restoration and renewal to Israel (Isa. 49:5-6; 53:10-12).

With the success of the topical sequence, the narrative can progress to the final sequence.

Sheffield, JSOT, 1983) disagrees with the traditional interpretation and argues that the Servant (whom he identifies with Deutero-Isaiah) was imprisoned by the Babylonians, but eventually saved from death; however see comments by Oswalt, Isaiah 40-66: 393-94. 


\section{f. Final Correlated Sequence}

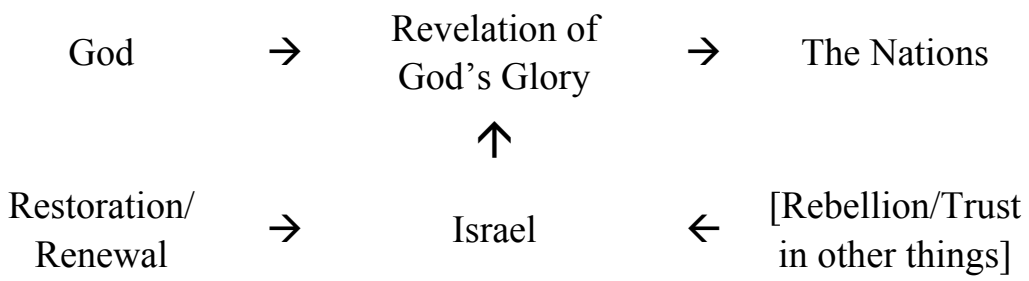

Through the ministry of the Servant, the main obstacle to Israel's mission to the nations, the need for spiritual renewal, is overcome. But there is another obstacle: the opposition of the nations themselves, and in particular, national pride and idolatry. We have seen that part of God's purpose in revealing his own glory is to humble those who exalt themselves. Thus, pride figures prominently in the reason for divine judgment on Assyria (Isa. 10:12-19), Babylon (Isa. 13:11, 19; 14:1214), Moab (Isa. 16:6) and Tyre (Isa. 23:9). Because these nations attributed their success and prosperity to their gods, they saw little need of the God of Israel, especially in view of Israel's relative weakness. And whilst the people of Israel and Judah were trying to make alliances with other nations, they were reinforcing the idea that their God could not be relied upon to help and protect them. In order to bring the nations to a place where they would acknowledge Israel's God, it would be necessary for God to demonstrate his power in the life of his people, by bringing them back from exile and vindicating them in the sight of the world. In Isaiah 40-55, God's ability to save his people (and to announce beforehand what he was going to do) is contrasted with the powerlessness of the nations and their gods (e.g. 41:21-29; $44: 6-20 ; 45: 16,20-22 ; 46: 1-7)$. And when the nations do see God's glory finally revealed in and through Israel, they will recognise that he is the only God - and will turn to him (e.g. Isa. 45:14; 60:1-3, cf. 2:2-4).

We have noted that Israel's mandate to be the agent through whom God's glory is revealed to the nations is linked with the Exodus, and that several passages in Isaiah 1-39 allude to the Exodus period - and in particular relate the presence of God on Sinai to his presence in Zion (e.g. $2: 2-4 ; 4: 5 ; 24: 23 ; 25: 6$ ). In Isaiah 40-55, Exodus traditions are 
also prominent, ${ }^{47}$ and the promised return from exile is described in terms of a second, and more glorious, Exodus. ${ }^{48}$ Second Exodus imagery is evident in the immediate vicinity of each of the Servant Songs (e.g. Isa. 42:13, 16; 49:8-12; 50:2-3; 52:10-12), and this supports the idea that the Servant may be seen as a second Moses. ${ }^{49}$ At the Exodus, Moses played a crucial role in the deliverance of Israel, and the revelation of God's glory. In this new and better deliverance, the Servant plays a crucial role, as the one through whom restoration and renewal is delivered to Israel, and with it the vindication and glorification that will cause the nations to finally recognise God's glory and acknowledge that he alone is God. This corollary to the final sequence may be represented as an additional sub-sequence.

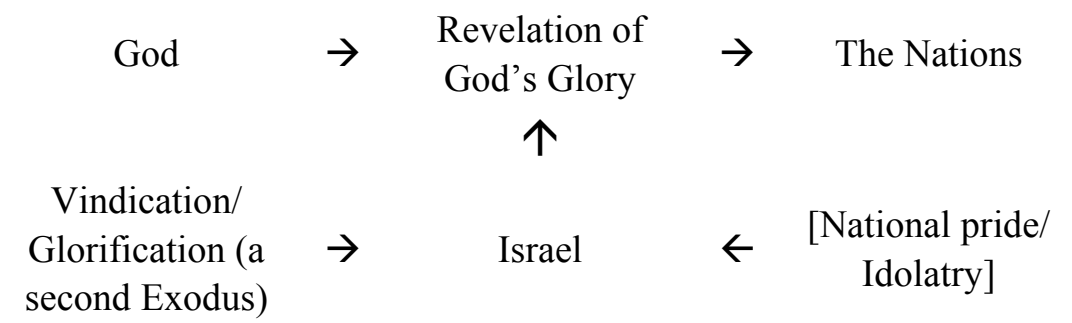

In this case, the vindication and glorification of Israel achieved in the main narrative, is sufficient to enable her to overcome the pride and idolatry of the nations, and so to fulfil her mandate.

This analysis indicates that we can go a considerable way towards identifying a narrative structure underlying the book - with a central

47 For further discussion see B. W. Anderson, 'Exodus Typology in Second Isaiah' in Israel's Prophetic Heritage: Essays in Honour of James Muilenburg, ed. B. W. Anderson and W. Harrelson (London: SCM/New York: Harper and Row, 1962): 17795; Bright, Kingdom of God: 136-55; Hugenberger, 'The Servant of the Lord in the "Servant Songs" of Isaiah': 119-39; C. R. North, 'The "Former Things" and the "New Things" in Deutero-Isaiah' in Studies in Old Testament Prophecy: Presented to T. H. Robinson, ed. H. H. Rowley (Edinburgh: T\&T Clark, 1950): 111-26.

48 God's victory at the Red Sea is alluded to in, e.g. Isa. 43:16-17; 51:9-10; he will make a way in the desert (Isa. 40:3), and as in the past (Isa. 48:21, cf. Exod. 17:2-7; Num. 20:8) will provide his people with what they need (Isa. 41:17-20; 43:19-20; 49:10); he will also protect his people (Isa. 52:12b, cf. Exod. 13:21-22; 14:19-20). The different character of the 'second Exodus' is seen in, e.g. Isa. 52:12a; cf. Exod. 12:11; Deut. 16:3; see also Isa. 40:4; 41:18-19; 49:9-11; 55:12-13.

49 See Hugenburger, 'The Servant of the Lord in the "Servant Songs" of Isaiah': 11939. K. Baltzer, Deutero-Isaiah (Hermeneia; Philadelphia: Fortress, 2001) interprets Deutero-Isaiah as a liturgical drama, based on the Feast of Passover/Unleavened Bread, with the Servant taking the part played by Moses. This view links with John's portrayal of Jesus as a second Moses. 
narrative theme, and related sub-narratives and sub-sequences. The analysis is not complete, but there is enough here to demonstrate the validity of the approach.

\section{Exegetical Implications}

There is an element of circularity in this approach, since a good deal of exegetical work needs to be done before a realistic narrative structure can be proposed. The value of this approach is that it helps to focus study and discussion. Instead of becoming lost in a complex maze of possibilities, the exegete is encouraged to look at the bigger picture: to consider the main theme and direction of the book. This can then be related to the various sub-themes of the book, whilst keeping those subthemes in proper perspective.

As we have seen, the initial correlated sequence and, in particular, the axis of communication, sets out the aim of the narrative. In the case of the Book of Isaiah, God as the Sender wants to reveal his glory (the Object) to the nations (the Receiver). Applying this structural model, therefore, the main concern of the book as a whole is the revelation of God's glory to the world. This approach recognises the importance of God's dealings with Israel, but sees them as a means to an end: an end that involves the nations recognising God's glory, turning to him, and so being included alongside Israel in a community of God's people. Once this identified as the main theme of the book as a whole, it gives us a basis for the interpretation of particular texts. For example it helps us to see that the pilgrimage of the nations in Isaiah 2:2-4 is not primarily about the exaltation of Zion. Zion is exalted, but only so that the nations may be drawn to the God who has made his dwelling there..$^{50}$ Similarly, passages that refer to the humiliation of the nations before Israel do not point to a lasting state of affairs. Israel must be glorified, and proud nations humbled - but only so that those nations may recognise God's presence among his people and either turn to him, or face the consequences.

50 Noting the link with Isa. 6:3, Eichrodt comments: 'this consummation was to convert into hard fact the vision of the King whose glory filled the whole earth' (Theology of the OT, 1:225). W. J. Dumbrell, The Faith of Israel (Leicester: Apollos, 1989): 98-111, argues that a key theme in the book is the transformation of Jerusalem; in these verses 'Jerusalem becomes the redemptive centre of the world' (p. 102). 
The narrative sub-structure also emphasises the crucial role of God's people. It is through them that the nations will see God's glory. In the initial and final sequences, the Subject is the same. Having failed to fulfil her mandate, Israel is not rejected but rather, in the topical sequence, becomes the Receiver of additional help so that her mission may be ultimately successful. The book emphasises God's concern for Israel; she is important to him, and her role, as God's servant, will be restored - though, again, not as an end in itself.

Another important exegetical implication relates to the Servant. We have noted that in this structural analysis, his narrative role is much more important than his identity. As the Subject of the topical sequence, that role is to bring to Israel what she needs to fulfil her mission: namely restoration and renewal. This emphasis on role rather than identity means that our interpretation is not bound up with our ability to say who the Servant is, and to be able to set his ministry within a historical context. It might even be possible to think of the Servant as a composite figure, incorporating all who are used by God to enable Israel to fulfil her mandate. This allows us to incorporate many of the traditional historical suggestions, whilst still looking forward to the ultimate fulfilment of the Servant's role in Christ.

Finally, the narrative sub-structure links the sections of the Book of Isaiah together. Though there is not an exact correspondence, the three sections may be broadly linked with the three narrative sequences. Isaiah 1-39 focuses on Israel's call, rebellion and failure - and opens up the need for, and possibility of, restoration. Isaiah $40-55$ is addressed to Israel in exile; it reaffirms her call as God's servant and promises restoration in the form of a second Exodus. The restoration and renewal of the people is closely linked with the ministry of the Servant. This moves the narrative on to Isaiah 56-66, which includes the promise that a renewed and restored Israel will reveal God's glory to the nations - and so fulfil her mandate. The narrative structure also links the Book of Isaiah with the rest of the Old Testament - and especially with the Exodus, which figures prominently in it.

This is only a brief summary, and the application of this approach needs to be worked out more thoroughly. What I hope to have shown is that the search for a narrative structure underlying the Book of Isaiah is valid, and has useful and important implications for how we understand and interpret the text. 